\title{
Ecological Investigations of the Influence of a Polluted River on Surrounding Interstitial Underground Waters
}

\author{
by \\ Milan MEŠTROV and Romana LATTINGER-PENKO*
}

\section{INTRODUCTION}

The object of this paper is to present our studies on interstitial subterranean waters, filling up tiny crevices among particles of the bottom of the streams and of beaches as well as of sand and gravel alluvial sediments of river valleys; i.e. postamostygal, mixopotamostygal and eustygal (Husmann 1975).

The phenomena of life and its features, along with the ever more and more important intersitial subterranean waters as a resource of drinking-water, involve biological and ecological studies side by side with the hydrogeological, chemical, physical and medical ones.

Quantity, physico-chemical characteristics and distribution of these subterranean waters are relatively well known on both regional and world scope. Though introductory studies of dynamics of composite ecological processes are progressing. Researches of natural habitats have scientific as well as practical values and some experiments were already performed (Husmann 1968, 1971, 1974/75; Ritterbusch 1976).

Ecological researches of interstitial waters include questions concerning the composition of the biocenosis and relations of its terrestrial and subterranean faunistic elements; relations between the structures of biocoenoses and physical features of substratum, e.g. volumes of intergranular spaces and its practicability for water circulation, temperature of water and $\mathrm{pH}$; relation to the chemistry of water and quantity of existing food (Lüpkes 1976, Husmann 1968). Studies of vertical and horizontal distribution and density of population depending on ecological factors, etc., have also been carried out (Husmann 1974/75, Danielopol 1976, Meštrov, Lattinger-Penko \& Tavčar 1976).

The attachment of certain subterranean organisms - stygobionts - i.e. of their communities to the biotopes of specific characteristics serves also as a

*) Certain chemical, faunistic, bacteriological and field studies and determinations have been performed by:Dr. I. Habdija, Dr. B. Stilinović and Dr. V. Tavčar.

Zoologijski zavod PMF, Rooseveltor trg 6/1, Zagreb I, Yougoslavia. 
determination of the degree of quality of underground waters in respect to human consumption (Husmann 1964, Spangenberg 1973).

Since the phreatic waters serve as drinking-water and as allochthonous environmental pollution develops, the understanding of connections and mutual influence of surface-waters - particularly polluted ones - to subterranean waters, is of special significance. For this purpose, various indicators have been used, such as fluorescent tracers (Giammona 1973) or radioactive ones (K ubelka - personal communication); the control of changing physico-chemical and biological parameters through a system of permanent bores (Husmann 1974/75), or provisional ones, are also used (Bou and Rouch's method).

The results here presented were attained during studies accomplished during 1973 and 1974 in the river Sava valley, not far from Zagreb - the Jankomir bridge - where a relatively shallow and fast current of the river circulates over thick alluvial sediment of sand and gravel watered by phreatic flows.

The aim of our studies is to attain a comprehension of condition, quality, connections and mutual influence of the river and surrounding subterranean hyporheic waters (potamostygal and mixo-potamostygal with the phreatic water (eustygal) in this contact zone as well as possible infiltration of surfacewater to the phreatic one and vice versa.

\section{METHODS}

The samples were taken on 29 June, 17 July, 3 November 1973 and 17 April 1974 during low water using the Bou-R ouch method, from various depths $(0.3-$ $2 \mathrm{~m}$ ), of crosswise profile including a portion of the left river bank, the beach and the bottom of river (Fig. 1). A Norton pump, driven down to $7 \mathrm{~m}$ was employed at the same location, $200 \mathrm{~m}$ distant from the river.

Determinations of certain bacteriological and chemical parameters of the river's water were accomplished as well as evaluation of the saprobiological conditions of the river and bacteriological, chemical and faunistic analyses of the samples of interstitial water. Bacteriological analyses were carried out only in the autumn and more extensive chemical analyses in the autumn and spring. All samples taken in 1973 were used for faunistic determinations.

- Number of Escherichia coli per $1 \mathrm{ml}$ was defined by counting the typical metal-glittering red colonies developed on the substratum of endo-agar after $24 \mathrm{~h}$ incubation at $37^{\circ} \mathrm{C}$.

- Number of heterotrophic bacteria was defined by the number of colonies grown on flesh-peptonic agar. The incubation lasted 4 days at $20^{\circ} \mathrm{C}$.

- Number of ammonification bacteria was determined by counting the reddish-yellow coloured colonies developed on membraneous filters after watering by Nessler's reagent - Daubner and Ritter's method.

- Saprobiological evaluation was defined according to Liebmann's method and Pantle-Buck's index of saprobity.

- Faunistic analysis was performed by examining 26 samples of intersitial water -12 aestival and 14 autumnal. The samples were taken on all points of 


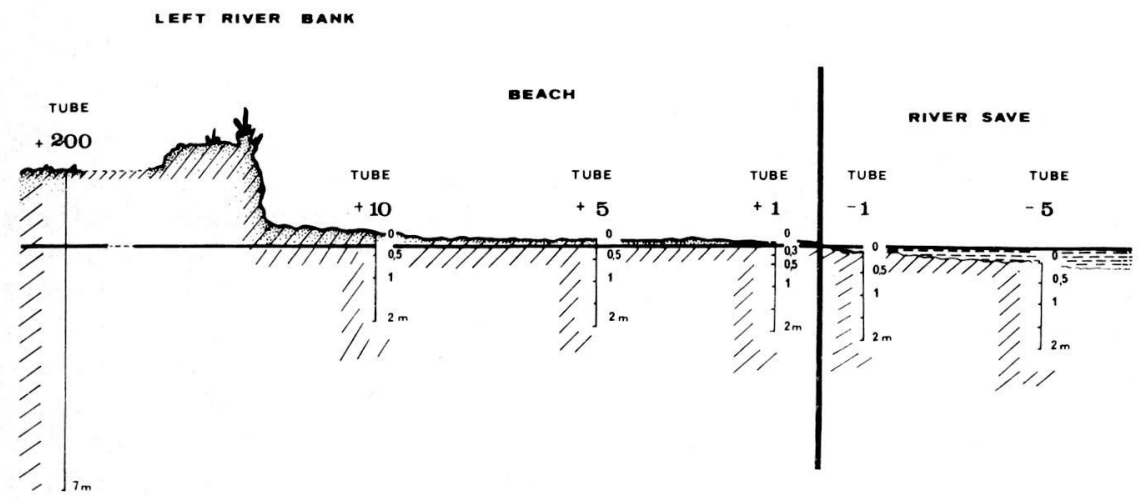

Fig. 1. THE RIVER SAVA NEARBY zagreb (JANKOMIR BRIDGE)

POSITIONS OF PUMPING TUBES, IE SAMPLING POINTS (NUMBERS INDICATE THEIR DEPTHS AND DISTANCES FROM THE RIVER EOGE,
IN METERS).

the profile by filtering certain quantity of water through a $80 \mu$ mesh mill-silk net. The animals were fixed in $4 \%$ formaldehyde.

- Temperature of water was measured during pumping with a laboratory thermometer $\left(1 / 10^{\circ} \mathrm{C}\right)$, the quantity of dissolved oxygen using the Winkler method, alkalinity and the quantity of free carbon dioxide titrimetrically with $\mathrm{N} / 10 \mathrm{HCl}$ and $\mathrm{N} / 20 \mathrm{NaOH}$. Biochemical oxygen demand, $\mathrm{BOD}_{2}$ was determined according to the standard method with no diluting. The incubation lasted $48 \mathrm{~h}$ at the temperature of $22-23^{\circ} \mathrm{C}$. Results obtained were presented in milligrams per litre and in percentage.

- Permanganate number or relative quantity of organic material was identified by oxydizing with $0.01 \mathrm{KMnO}_{4}$ after $10 \mathrm{~min}$. of boiling the sample of $100 \mathrm{ml}$ content.

- nitrates, nitrites and ammonia were defined colorimetrically i.e. nitrates by the brucine method, nitrites with alpha-naphtilaminic and sulphanilic acid and ammonia through direct neslerisation.

- Chlorides were determined by the $\mathrm{AgNO}_{3}$ method.

- Concentration of $\mathrm{H}$-ions was measured by a standard pH-meter, MA-5701 Iskra, Kranj.

- Evaporative remains were obtained by evaporation of water - using the infra-sol lamp- and dried at $104^{\circ} \mathrm{C}$.

- Loss during the ignition was obtained by $4 \mathrm{~h}$ heating at $320^{\circ} \mathrm{C}$.

- Suspended matter. The quantity of organic and inorganic particles in the samples was determined by quantitative difference between evaporative remains of unfiltrated water and water filtered through a cotton-wool filter. It was not possible to separate organic from inorganic parts.

- Anionic surface-active agents ("surfactants") were measured colorimetrically after the treatment of a sample with methylencblue and chloroform, - the method of Longwell and Maniece. The quantity is defined in $\mathrm{mg} / \mathrm{l}$ as tetrapropylenbenzolsulphonate (TBS/1/650 $\mathrm{nm}$ ). 


\section{RESULTS}

\subsection{Fauna of researched hyporheic}

The faunistic analysis of interstital water samples revealed the presence of the following animal groups in the area of investigation: Nematoda, Oligochaeta, Copepoda, Ostracoda, Amphipoda, larvae of insects (Chironomidae, - others rarely) and Gastropoda (Tables I, II, III). The most diverse composition was found at $0.3-0.5 \mathrm{~m}$ depth and all mentioned groups were found down to that depth in the hyporheic. But in $7 \mathrm{~m}$ depth and $200 \mathrm{~m}$ away from the river, no animal material was observable in $200 \mathrm{l}$ of filtered water. Almost all bores (points) of the cross-profile displayed Oligochaeta as the prevailing group by number of specimens - considering both time and space distribution. The density of the population of Oligochaeta diminished according to the depth of substratum; below $1 \mathrm{~m}$ depth they were difficult to find or completely absent. - Nematoda were found in comparatively little number only in some aestive samples. Only one specimen was found in $2 \mathrm{~m}$ depth in the autumn.

- Copepoda appeared sporadically and in small numbers. They were observed in the summer as well as in autumn but never below $1 \mathrm{~m}$ depth.

- Ostracoda were found individually and sporadically. Living specimens were found down to $1 \mathrm{~m}$ depth, occasionally to $2 \mathrm{~m}$. Frequently, shells of dead animals were found.

- Amphipoda. Only one specimen of Gammarus fossarum was found in 0.5 and $1 \mathrm{~m}$ depths. The single subterranean organism (Niphargus $\mathrm{sp}$.) in this area was found in the benthos of the river.

- Larvae of insects, predominantly Chironomidae, were found more frequently than any other group of animals, except for Oligochaeta. They were found usually down to $0.5 \mathrm{~m}$ and exceptionally to $1 \mathrm{~m}$ depth.

- Gastropoda. The terrestrial forms were found infrequently in several aestival samples down to $1 \mathrm{~m}$ depth.

- Gemmules and spicules of sponges were found in $0.5 \mathrm{~m}$ depth.

- Empty tubes of the larvae of Trichoptera, particles of coal (deriving from the mines up river), threads of Sphaerotilus as well as the remnants and living organisms, - indicative of a high degree of saprobity - were present down to $2 \mathrm{~m}$ depth.

\subsection{Saprobiological analysis of the river Sava water}

Flowing from Slovenia, the river Sava at Zagreb is already considerably polluted by organic and inorganic discharge matters. This is evidenced from several years' pollution-degree control of the river (Meštrov, Dešković \& Tavčar 1976) as well as by the analyses carried out during our studies. The river Sava was marked alpha-mesosaprobic with the index of saprobity 3.3 for pedon and 2.8 for seston. Simultaneously the presence of dead algae and also a small number of living indicative species of algae and bacteria were found in the interstitial water of the beach and in the river bed - down to $2 \mathrm{~m}$ depth.

\subsection{Bacteriological analysis of the river and surrounding interstitial water}




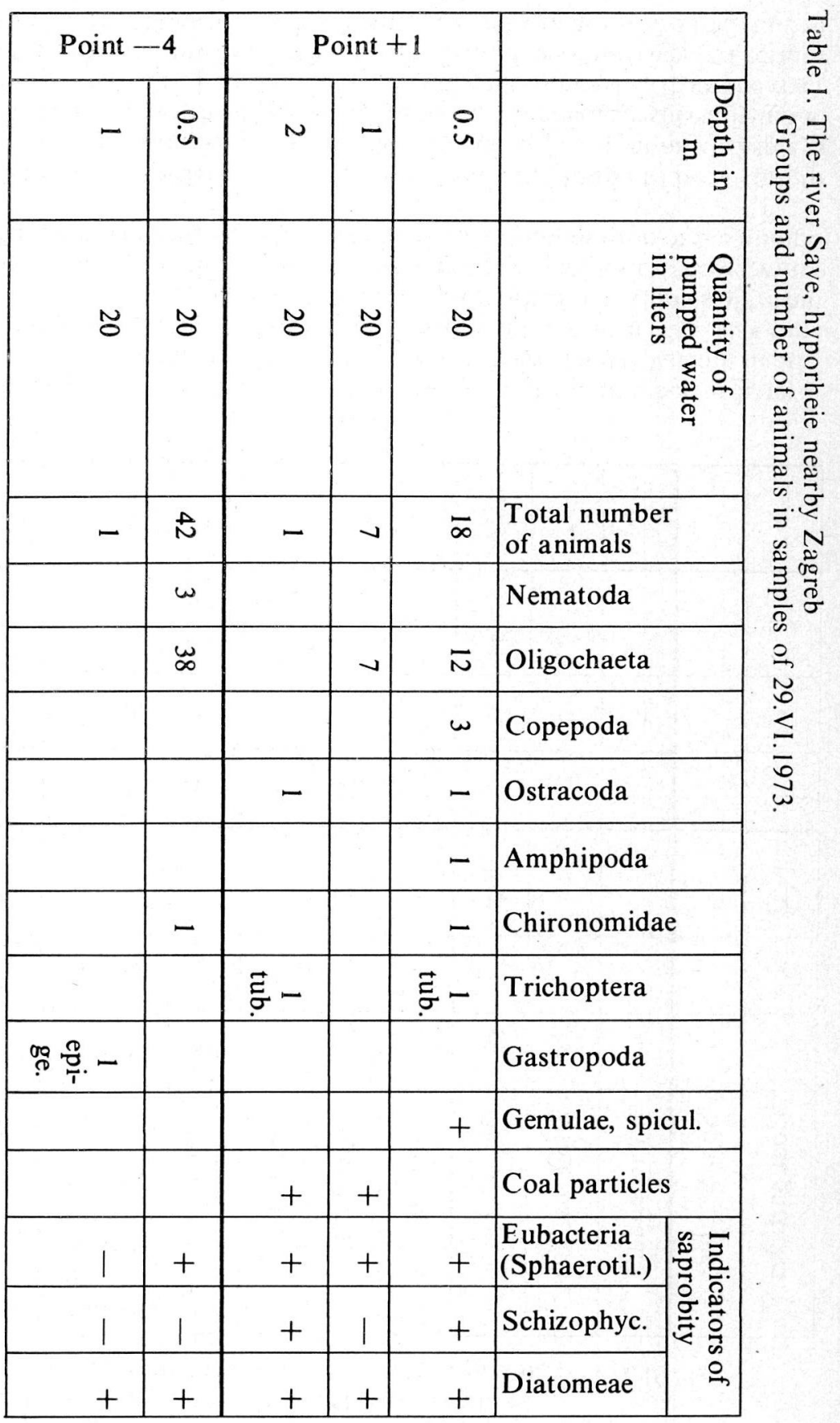


Table II. The river Save, hyporheie nearby Zagreb

Groups and number of animals in samples of 17.VII.1973.

\begin{tabular}{|c|c|c|c|c|c|c|c|c|c|c|c|}
\hline & $\begin{array}{l}\text { Depth } \\
\text { in } \\
\text { m }\end{array}$ & $\begin{array}{l}\text { Quantity } \\
\text { of } \\
\text { pumped } \\
\text { water } \\
\text { in } \\
\text { liters }\end{array}$ & 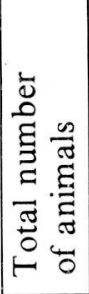 & 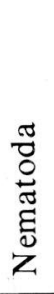 & 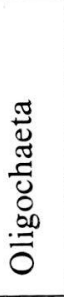 & $\begin{array}{l}\frac{\pi}{0} \\
0 \\
\frac{0}{0} \\
0 \\
0 \\
0\end{array}$ & 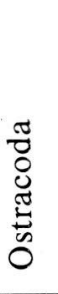 & 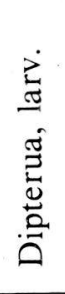 & 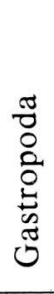 & 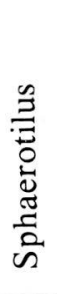 & 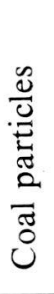 \\
\hline \multirow{3}{*}{$\begin{array}{l}\overline{+} \\
\stackrel{\Xi}{0} \\
0\end{array}$} & 0.5 & 40 & 64 & & 61 & 1 & 1 & & 1 & & \\
\hline & 1 & 40 & 7 & 1 & 5 & & 1 & & & & \\
\hline & 2 & 40 & 2 & 1 & 1 & & $\begin{array}{l}3 \mathrm{x} \\
1 / 2\end{array}$ & & & + & + \\
\hline \multirow{3}{*}{$\begin{array}{l}n \\
+ \\
\pm \\
.0 \\
0\end{array}$} & 0.5 & 40 & 18 & 1 & 17 & & & & & & \\
\hline & 1 & 40 & 8 & 2 & 2 & & $1 / 2$ & & 4 & & \\
\hline & 2 & 40 & 1 & & 1 & & $\begin{array}{l}3 \mathrm{x} \\
1 / 2\end{array}$ & & & & \\
\hline $\begin{array}{l}\vec{Z} \\
0 \\
0\end{array}$ & 0.5 & 40 & 218 & 3 & 215 & & $\begin{array}{l}5 \mathrm{x} \\
1 / 2\end{array}$ & 1 & & & \\
\hline
\end{tabular}

The determination of number of Escherichia coli and the number of heterotrophic and ammonification bacteria per $1 \mathrm{ml}$ were carried out in various depths of the beach and of the river botiom at 5 points indicated in Fig. 1 as tube $+10,+5,+1,-1$ and -5 . At the same time were studied the samples of turbid water obtained at the beginning of pumping and the samples of limpid water taken at the same sampling site after several minutes of operation of the pump.

3.3.1. Number of Escherichia coli in the river-water was found to be $60 / \mathrm{ml}$. In comparison with the samples of interstitial water (Fig. 2), this number displays an augmentation toward the depth of $0.5 \mathrm{~m}$ by the water edge, especially in the river bottom. In the same horizon the number of cells diminishes from the river margin in the direction toward the bank and the middle of the river. At certain sites the number increases toward the depth of $1 \mathrm{~m}$ by factor of 2.5 to 5 ; to $2 \mathrm{~m}$ 
Table III. The river Save, hyporheie nearby Zagreb

Groups and number of animals in samples of 3.XI.1973.

\begin{tabular}{|c|c|c|c|c|c|c|c|c|c|c|}
\hline & $\begin{array}{l}\text { Depth } \\
\text { in } \\
\text { m }\end{array}$ & $\begin{array}{l}\text { Quantity of } \\
\text { pumped water } \\
\text { in litres }\end{array}$ & 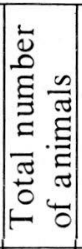 & $\begin{array}{l}\frac{\pi}{0} \\
0 \\
\tilde{\pi} \\
\tilde{D} \\
z\end{array}$ & 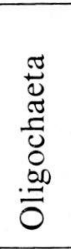 & $\begin{array}{l}\frac{\pi}{0} \\
0 \\
0 \\
0 \\
0 \\
0 \\
ن\end{array}$ & 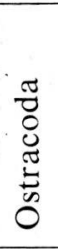 & 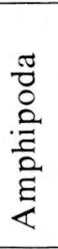 & 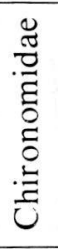 & 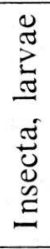 \\
\hline \multirow{4}{*}{$\begin{array}{l}7 \\
+ \\
. \\
0\end{array}$} & 0.3 & 10 & 24 & & 11 & 3 & 1 & & 5 & 4 \\
\hline & 0.5 & 40 & 10 & & 6 & 1 & & & 3 & \\
\hline & 1 & 20 & 6 & & 4 & 1 & 1 & & & \\
\hline & 2 & 20 & 0 & & & & & & & \\
\hline \multirow{3}{*}{$\begin{array}{l}n \\
+ \\
. \\
0 \\
0\end{array}$} & 0.5 & 40 & 6 & & & 5 & & & 1 & \\
\hline & 1 & 20 & 4 & & & & & 1 & 3 & \\
\hline & 2 & 10 & 1 & 1 & & & & & & \\
\hline \multirow{2}{*}{$\begin{array}{l}0 \\
+ \\
\pm \\
. ! \\
0 \\
0\end{array}$} & 1 & 40 & 15 & & 12 & 1 & 1 & & 1 & \\
\hline & 2 & 5 & & & & & $\begin{array}{l}2 x \\
1 / 2\end{array}$ & & & \\
\hline \multirow{3}{*}{$\begin{array}{l}\vec{I} \\
\overrightarrow{0} \\
0\end{array}$} & 0.5 & 40 & 10 & & 2 & & & & 8 & \\
\hline & 1 & 40 & 2 & & 1 & 1 & & & & \\
\hline & 2 & 20 & & & & & $1 / 2$ & & & \\
\hline \multirow{2}{*}{$\begin{array}{l}n \\
\stackrel{n}{0} \\
2\end{array}$} & 0.5 & 40 & 6 & & 3 & 2 & & & 1 & \\
\hline & 1 & 40 & 1 & & 1 & & $\begin{array}{l}2 x \\
1 / 2\end{array}$ & & & \\
\hline
\end{tabular}




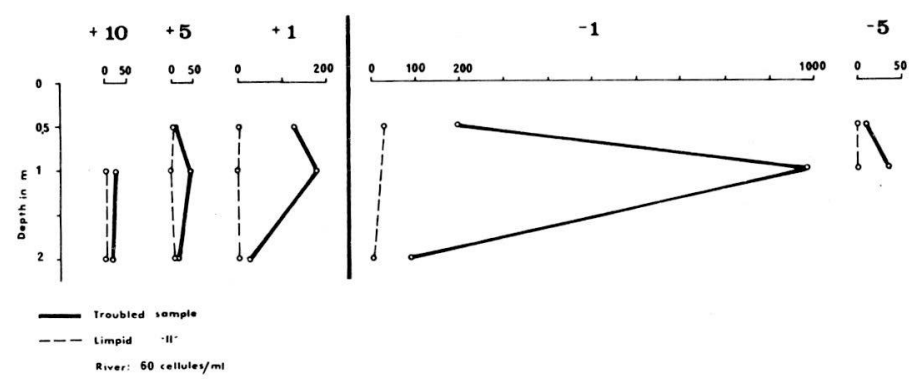

FIG. 2. NUMBER OF ESCHERICMIA COLI CELLS IN 1 mI OF HYPORHEIC WATER. 3.11. 1973.

depth it is decreasing at alle sites, usually below the number noted for the depth of $0.5 \mathrm{~m}$. The greatest number of cells was recorded at the bottom by riverside, and the smallest at the point +10 . Both recordings were made at $1 \mathrm{~m}$ depth.

In turbid samples Escherichia coli exceed in number those found in limpid ones. This is due to a relation between the bacteria and sediment particles. However, at $0.5 \mathrm{~m}-1 \mathrm{~m}$ depth this value deminishes; down to $2 \mathrm{~m}$ it is either increasing (points +5 and +1 ) or unchanging (point +10 ) and at the bottom by the water edge the value is still less (point -1 ).

\subsubsection{Number of heterotrophic bacteria}

There were found 18600 heterotrophic bacteria per $1 \mathrm{ml}$ of the river's water. Their number is considerably decreased in the sediment, down to $0.5 \mathrm{~m}$ depth. But the decrease is far greater at the beach than at the river bottom (Fig. 3).

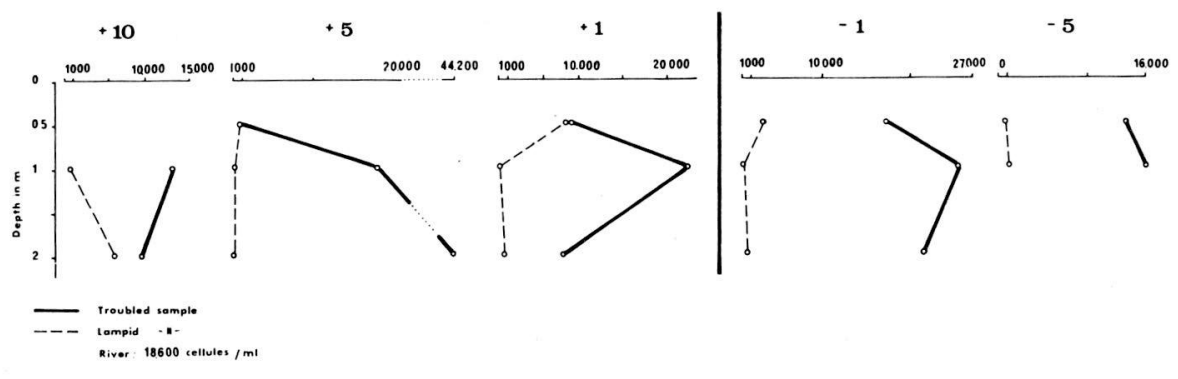

FIG. 3. NUMBER OF HETEROTROFIC BACTERIA IN ImIOF HYPORHEIC WATER. 3111973

As with Escherichia coli, the number of heterotrophic bacteria increases down to $1 \mathrm{~m}$ and in adjoining area to the margin of the river exceeds the number found in the river water. Here again, the difference is more explicit at the river bottom than in the alluvial soil. Similarity with the Escherichia coli displays also in the decrease of heterotrophic bacteria down to $2 \mathrm{~m}$ at all points as well as in the fact that the greatest number has been recorded at point -1 . 
Inversion at the point +5 is an exception. Here, the number of heterotrophic bacteria in $2 \mathrm{~m}$ depth is more than twice the number at $1 \mathrm{~m}$ depth.

In muddy samples the heterotrophic bacteria exceed in number these found in clear samples and the tendency of increase or decrease at all points by the depth in clear samples is opposite in turbid water.

\subsubsection{Number of ammonification bacteria}

In a sample of $1 \mathrm{ml}$ of the river water were found 2,800 ammonification bacteria. Their number increases down to $0.5 \mathrm{~m}$ both in the river bottom and alluvial soil (Fig. 4, points $+1,-1,-5$ ), and it is considerably smaller at a point farther from the river (point +5 ). At the first three points down to $1 \mathrm{~m}$ depth, the number of ammonification bacteria decreases, while at point +5 it increases. Down to $2 \mathrm{~m}$, the tendency of growth and diminution of ammonification

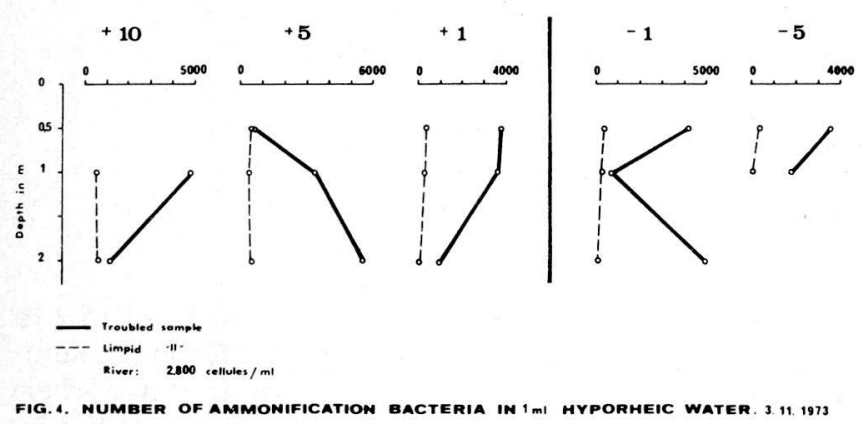

bacteria in number varies. There are twice the number of ammonification bacteria in the middle of alluvial soil (point +5 ) and in the bottom by the water edge (point -1) than in the river, and in the beach along the margin of the water (point +1 ) as well as at the most distant (point +10 ) their number is considerably reduced.

The limpid samples contain considerably less ammonification bacteria than turbid ones.

3.4. Physico-chemical analysis of the river Sava's water and surrounding interstitial waters

\subsubsection{Temperature of water}

At the beginning and in the middle of summer (29 June, $17 \mathrm{July} \mathrm{1973)} \mathrm{tempera-}$ ture of the river water was recorded as $21^{\circ} \mathrm{C}$, in the autumn (3 November 1973) $6.5^{\circ} \mathrm{C}$ and in the next spring (17 April 1974) $10.2^{\circ} \mathrm{C}$.

The spring temperature recordings of hyporheic water were in all measurement points lower than the river water by $0-2.7^{\circ} \mathrm{C}$, in the early summer by 3$5.8^{\circ} \mathrm{C}$ and in the middle of summer by $2.5-5^{\circ} \mathrm{C}$. On the contrary, in the autumn hyporheic water was warmer by $4.1-6.5^{\circ} \mathrm{C}$.

Temperature of the hyporheic water decreases in the summer to a depth of 

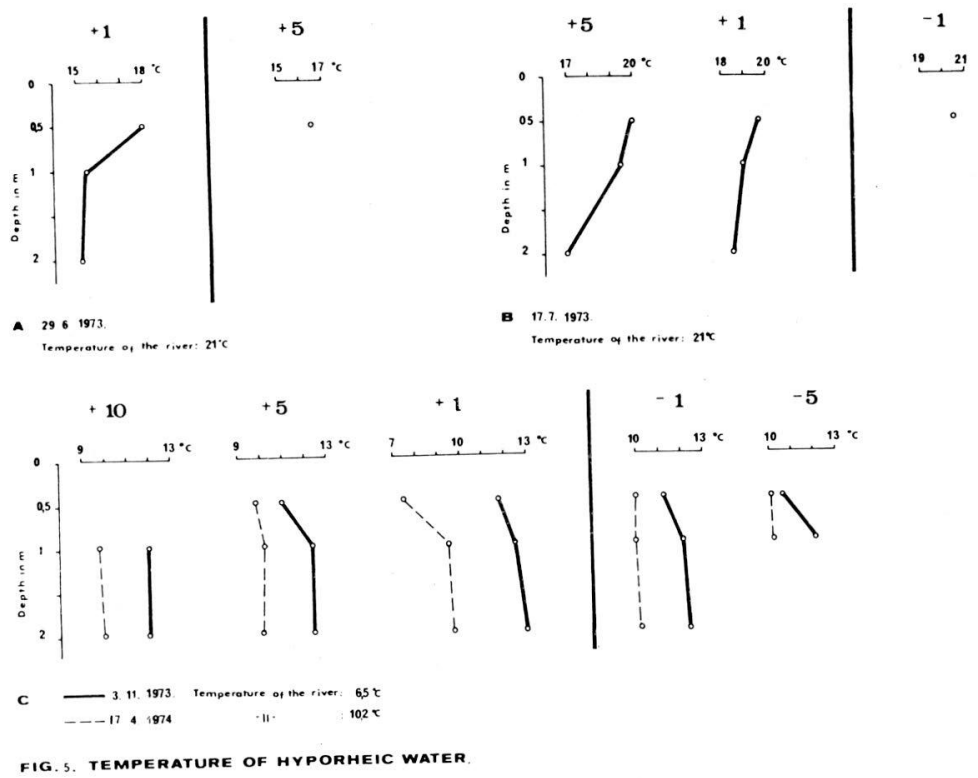

$2 \mathrm{~m}$; at $0.5 \mathrm{~m}$ depth the temperature ranged from 18 to $20^{\circ} \mathrm{C}$ and from 15.2 to $18.5^{\circ} \mathrm{C}$ in $2 \mathrm{~m}$ depth (Fig. 5). The differences vertically are greater in the summer considering the area more distant from the river. The water of hyporheic below the beach, nearer to the river ( $1 \mathrm{~m}$ from the river's margin) is cooler by $0.3-0.5^{\circ} \mathrm{C}$ down to $1 \mathrm{~m}$ depth than the water of more distant hyporheic $(5 \mathrm{~m}$ away); at $2 \mathrm{~m}$ depth the temperature conditions are opposite.

The temperature of hyporheic water increases in depth in the autumn and spring but the differences in vertical measurements at certain points are smaller than in the summer (the smallest are in the spring). The more distant from the river, the smaller are the differencies. At the horizon at $0.5 \mathrm{~m}$ depth the values are 7.5 to $11.8^{\circ} \mathrm{C}$ compared to $10-13^{\circ} \mathrm{C}$ at $2 \mathrm{~m}$ depth. Fig. 5 demonstrates that the differences at $0.5 \mathrm{~m}$ depth are more considerable than at $1-2 \mathrm{~m}$ depth. At the point +200 , far on the riverside and $7 \mathrm{~m}$ depth, temperature of water recorded $8.5^{\circ} \mathrm{C}$.

\subsubsection{The quantity of dissolved oxygen}

In the river water the quantity of $1.45 \mathrm{mg} / 1$ of dissolved oxygen is recorded at the first summer measurement, and of $3.1 \mathrm{mg} / \mathrm{l}$ at the second one. In both cases the water temperature was $21^{\circ} \mathrm{C}$. The autumnal sample recorded was $4.5 \mathrm{mg} / \mathrm{l}$, which means, at the temperature of $6.5^{\circ} \mathrm{C}$, the deficiency of $63.5 \%$ (Fig. 6a). The vernal measurement has a value of $4.6 \mathrm{mg} / 1$ by temperature of $10.2^{\circ} \mathrm{C}$.

Both summer measurements showed that the hyporheic water contains very small quantities of oxygen: except for the value of $2.5 \mathrm{mg} / \mathrm{l}$ at the depth of 


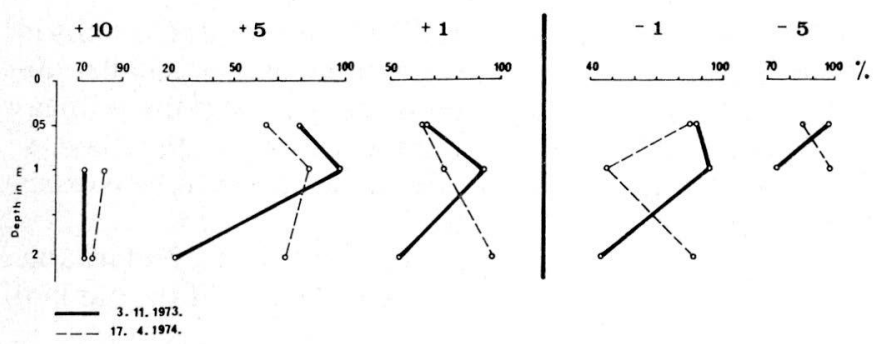

FIG. 6a DEFICIENCY OF OXYGEN IN HYPORHEIC WATER, IN \%.

$0.5 \mathrm{~m}$ in the river bottom near the water edge, all measurement points recorded quantities less than $1 \mathrm{mg} / \mathrm{l}$ (Fig. 6).

In the autumn and spring larger quantities of $\mathrm{O}_{2}$ were recorded at corresponding points than in the summer.

Comparing four measurements in the profile we note that the hyporheic water has almost always a smaller quantity of oxygen than the river.

With regard to the river this quantity rapidly reduced to the depth of $1 \mathrm{~m}$. Towards the horizon on $2 \mathrm{~m}$ depth in summer months the quantity of $\mathrm{O}_{2}$ still diminishes, to a trace, or it slightly rises (point +10 ). But in the autumn in this deepest layer there rapidly occurs an increase of dissolved oxygen. This rapid increase is especially evident in the zone of hyporheic along the edge of the river, which includes in its width about $5 \mathrm{~m}$ of the beach and $1 \mathrm{~m}$ of the river's bottom.
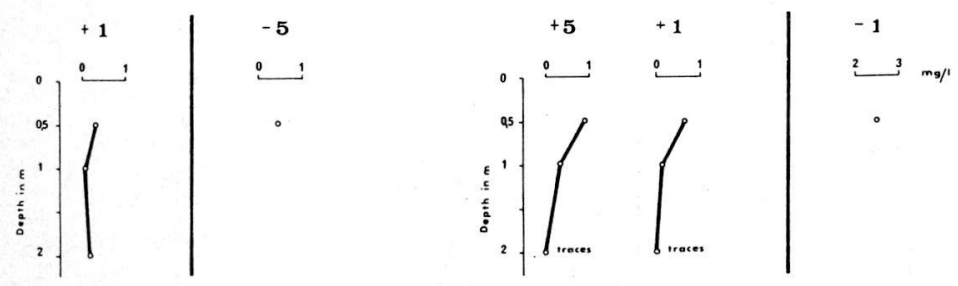

A. 2961973

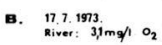

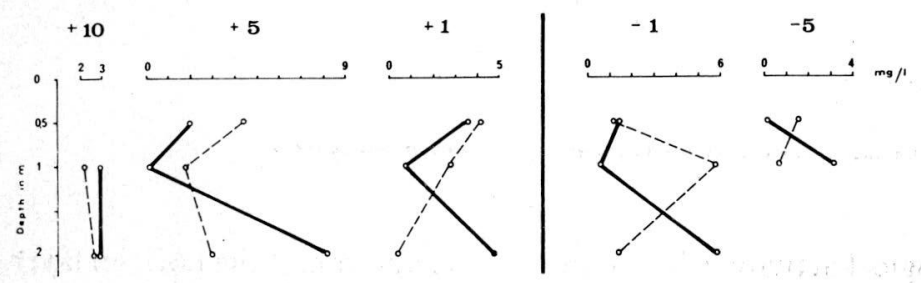

C - River $45 \mathrm{mg} / 1 \mathrm{O}_{2}$

FIG.6. QUANTITY OF DISSOLVED OXYGEN IN HYPORHEIC WATER, IN mg/4 
The disposition of the quantity of oxygen at studied locations and depths in the spring corresponds to that in the autumn (but with greater or smaller absolute values) only at the water edge; an exception is the deepest point of measurement near the river where the $\mathrm{O}_{2}$-quantity is smaller than in upper layers. There is an inversion compared to the autumnal situation. This inversion exists at all depths of the bottom along the edge of the river.

The point -5 , far from the shore on the river bottom, seems remarkable since its gradients are quite opposite to those from the bottom near the bank of the river.

The point +10 is different from others by a slight variation of $\mathrm{O}_{2}$ quantity with the depth.

At the point +200 the quantity of $0.8 \mathrm{mg} / 1 \mathrm{O}_{2}$ is recorded by temperature of $8.5^{\circ} \mathrm{C}$. which means a deficiency of $93.2 \%$.

\subsubsection{Biochemical oxygen demand, $B O D_{2}$}

This indicator for the intensity of bacteriological activity was determined only in the autumnal and aestival samples (Fig. 7).

The striking feature is that all values of BOD in percentage both in the water of hyporheic and river are greater in the spring than in autumn.

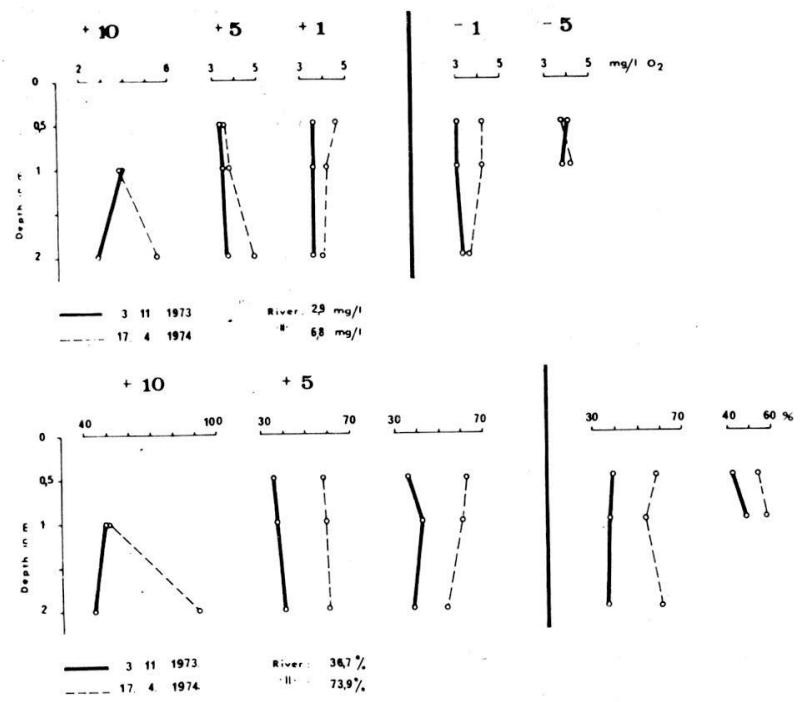

FIG.7. TWO DAYS' BIOCHEMICAL OXVGEN DEMAND PRESENTED IN mg/I AND IN PERCENTAGE

The bacteriological activity is in progress in the autumn at the horizon layer at $0.5-1 \mathrm{~m}$ depth from the point +5 on the river edge toward the most distant point in the river bed (-5). The values increase from $35.4 \%$ to $43.1 \%$ at $0.5 \mathrm{~m}$ depth and from $37.2 \%$ to $47.8 \%$ at $1 \mathrm{~m}$ depth. 
The peripheral points of the profile $(+10$ and -5$)$ show considerably greater values of BOD than other points.

The centre of the bacteriological activity of shallow layers moved in the spring from the most distant point in the river bed to the waterside just at the margin of water (point +1 ). But only slightly smaller values were obtained in same horizons both in the bottom at waterside and $5 \mathrm{~m}$ far away on the river bank.

Except for the point +1 at which BOD decreases in the spring by depth, at all other points the values rise. The point +10 is characteristic of definite greatest BOD values.

The sample taken at the point +200 shows a $\mathrm{BOD}_{2}$ amount of $4 \mathrm{mg} / \mathrm{l}$, i.e. $57.1 \%$.

\subsubsection{Permanganate number or $\mathrm{KMnO}_{4}$ consumption}

To define this parameter, two samples were taken from all sites in the autumn: the first (permanganic number I) sample of water around the top of the drill together with the detritus and the second (permanganate number II) sample of water from more extensive areas around the drill, already clear due to filtering through sand and gravel substratum. Only clear water was used in the spring.

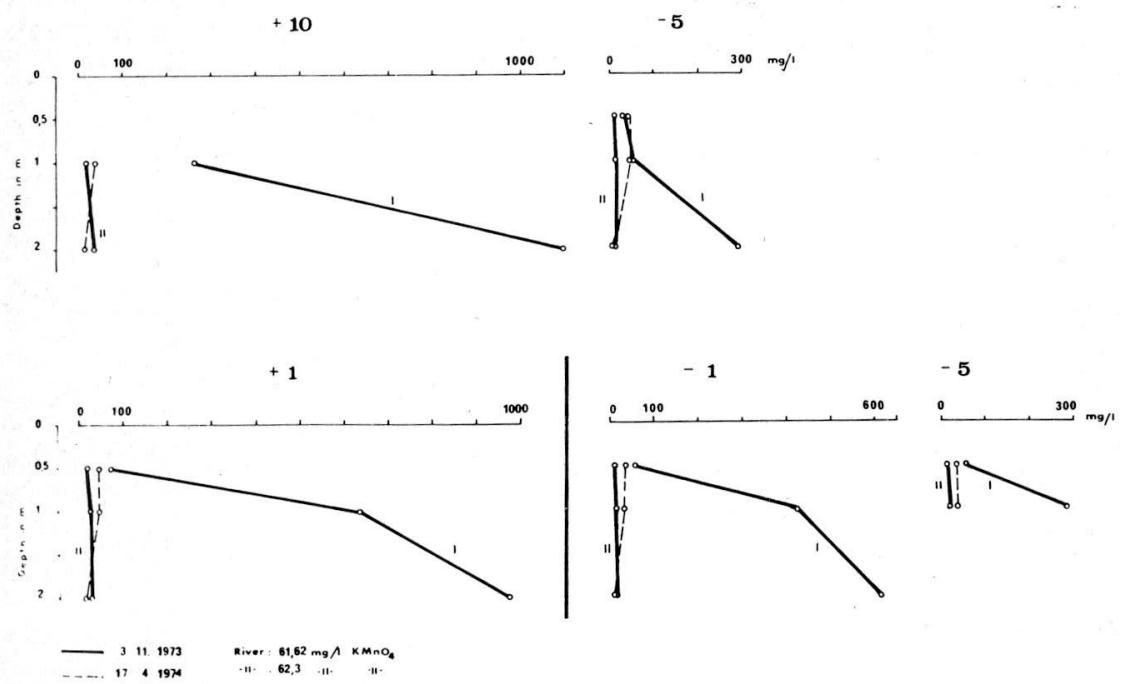

Fig a PERmanganate nUmber OR $\mathrm{KMnO}_{4}$ CONSUMPTION, in mg/l.

The results are presented in figure 8 .

The permanganate number for the river water was recorded as $61.62 \mathrm{mg} / \mathrm{l}$ $\mathrm{KMnO}_{4}$ in the autumn and $62.3 \mathrm{mg} / \mathrm{l}$ in the spring.

- The autumnal hyporheic: Permanganate number I demonstrates that the 
shallow layer of hyporheic at $0.5 \mathrm{~m}$ depth retains organic materials to a lesser extent than river water. However, at all points the content of organic materials increases considerably by depth. There is an apparent tendency of an increase of permanganate number in all depths approaching the margin of the river from the point +5 on the riverside and a decrease at the bottom of the river.

Except for point +10 , the greatest values of permanganate number I were found at the beach near the river. The exceptional location, $10 \mathrm{~m}$ away from the margin of the river, features an increased quantity of organic materials greater than all other points of measurement. The highest value of $1099 \mathrm{mg} / 1$ was recorded at $2 \mathrm{~m}$ depth.

The permanganate number II is considerably smaller at the same points as permanganate number I but displays the same increasing tendency - in vertical sense, by depth - and the same horizontal progression and regression. However, vertical differences at certain points are considerably smaller.

- The vernal hyporheic: According to the vernal samples hyporheic retains very small quantities of dissolved organic materials, - considerably less than the actual river's content. But in the shallow layers the quantities are still greater than in the autumn.

A less distinctive comulative value for $0.5 \mathrm{~m}$ deep layer in the border of the beach is obtained by comparing certain points of measurement according to the horizons with the autumnal data. Contrary to the autumnal gradient, the permanganat number is smaller between the depths of 1 and $2 \mathrm{~m}$ at all points. The minimal value of $7.9 \mathrm{mg} / 1 \mathrm{KMnO}_{4}$ was recorded at the point +200 .

\subsubsection{Nitrates, nitrites and ammonia}

\subsubsection{Nitrates (Fig. 9)}

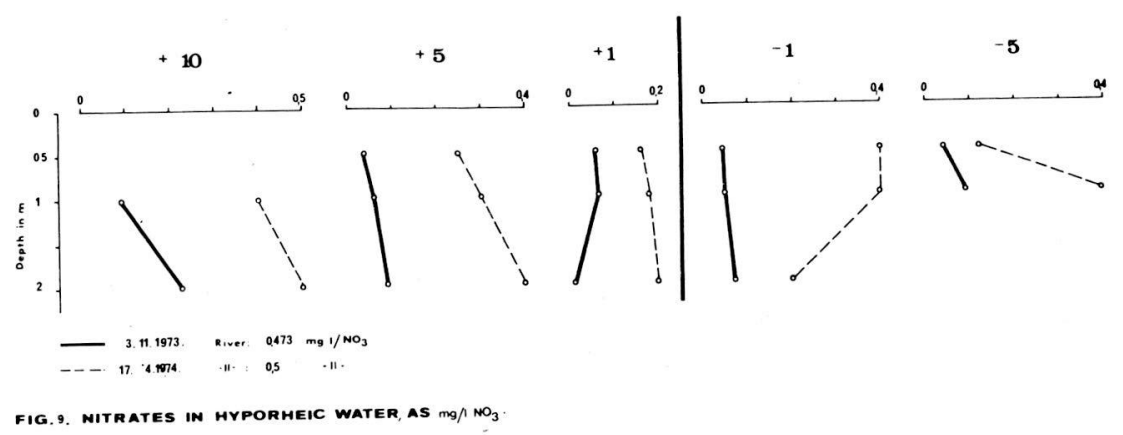

In the autumn the river Sava contained $0.475 \mathrm{mg} / 1 \mathrm{NO}_{3}$. Considerably less was noted in hyporheic water: from 0.04 to $0.23 \mathrm{mg} / \mathrm{l}$. The greater the depth, the more quantity of $\mathrm{NO}_{3}$ was found at all points. The quantity of $\mathrm{NO}_{3}$ increases horizontally from the middle of alluvium (point +5 ) toward the edge of the waterside (point +1 ) where the maximal values were recorded. It decreased from here toward the river bottom. The exception in this regularity is point -5 where in $1 \mathrm{~m}$ depth quantity of $\mathrm{NO}_{3}$ increases in comparison with $\mathrm{NO}_{3}$ 
quantity at the neighbouring point in the same horizon. The greatest quantity of $\mathrm{NO}_{3}$ was found in $2 \mathrm{~m}$ depth at the most distant point +10 .

In the spring the Sava contained more $\mathrm{NO}_{3}(0.5 \mathrm{mg} / \mathrm{l})$ and also the whole studied profile showed greater quantities than in the autumn. As in the autumn the increase by depth remained unchanged as well as the maximal value at the point +10 . But the comparison of points in the same layer shows $\mathrm{NO}_{3}$ quantity decreasing from the riverside toward the border of the beach. At the point +200 was recorded $0.5 \mathrm{mg} / 1 \mathrm{NO}_{3}$.

\subsubsection{Nitrites (Fig. 10)}

In the autumn the $\mathrm{NO}_{2}$ content in the river Sava was recorded as $0.078 \mathrm{mg} / \mathrm{l}$. Down to $1 \mathrm{~m}$ depth of hyporheic considerably less $\mathrm{NO}_{2}$ was found than in the river. In $2 \mathrm{~m}$ depth - except for the point +10 - there was at all measurement points more $\mathrm{NO}_{2}$ than in the river. The quantities recorded 0 to 0.178 $\mathrm{mg} / \mathrm{l}$. All points demonstrated a tendency of $\mathrm{NO}_{2}$ to increase by depth as well as

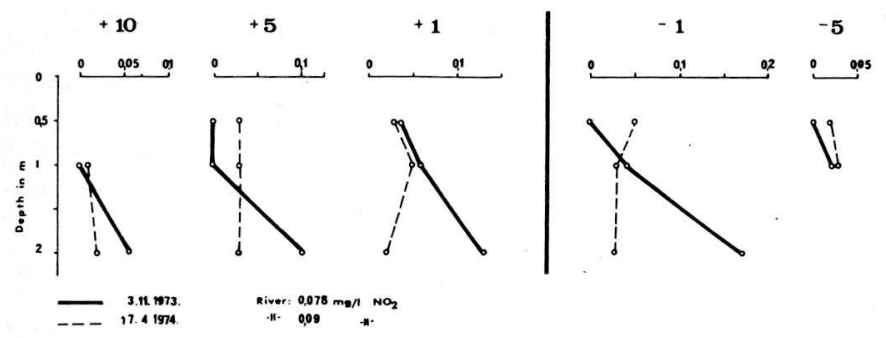

FIG.10. NITRITES IN MYPORHEIC WATER, AS mg/ $\mathrm{NO}_{2}$

horizontally - from the river bank toward the bottom by the water edge. Here, at $2 \mathrm{~m}$ depth a maximal value of $0.178 \mathrm{mg} / 1$ was recorded. The quantity of $\mathrm{NO}_{2}$ in the river Sava slightly increased in the spring in comparison with the autumnal values. It was recorded $0.09 \mathrm{mg} / \mathrm{l}$. Also, most points in hyporheic level down to $1 \mathrm{~m}$ depth recorded slightly more $\mathrm{NO}_{2}$ than in the autumn but this time the changes by depth were less. So, at a depth of $2 \mathrm{~m}$ was found considerably less $\mathrm{NO}_{2}$ than in the autumn.

At the point $+2000.03 \mathrm{mg} / 1 \mathrm{NO}_{2}$ was recorded.

\subsubsection{Ammonia (Fig. 11)}

In the autumn $0.41 \mathrm{mg} / \mathrm{l}$ ammonium nitrogen was measured in the river Sava. Shallow layers contained less ammonium nitrogen but more was recorded at a depth of $2 \mathrm{~m}$ than at the bottom by the waterside (point -1 ) and farther on at the peripheral point of the beach (point +10 ).

The quantity of ammonium nitrogen increases at all points by the depth as well as in horizontal sense - from the middle of the beach toward the margin of the river. Greater quantities of nitrogen were recorded in the river bottom than in the alluvial soil. 


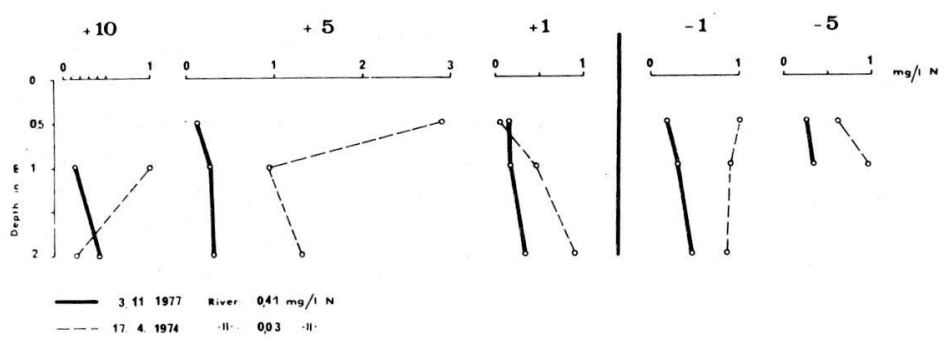

FIG. 11. AMMONIA IN HYPORHEIC WATER, AS Mg/' AMMONIA N

The point +10 with $0.45 \mathrm{mg} / 1 \mathrm{~N}$ at $2 \mathrm{~m}$ depth was again an exception.

Considerably less $-0.03 \mathrm{mg} / 1$ of $\mathrm{N}$ - was found in the Sava in the spring than in autumn but hyporheic water at the same time had values 5 to 100 times as much. The greatest quantities were found in the middle of the beach (point +5 ). Any regular rise of $\mathrm{N}$-quantity by depth of substratum could not be determined in this season. The quantities of $\mathbf{N}$ decreased on both sides of the river margin, particularly at a distance of $5 \mathrm{~m}$ on the beach at $0.5-1 \mathrm{~m}$ depth. Down to $2 \mathrm{~m}$ depth it rises again or slightly decreases. The $\mathrm{N}$-quantity slowly increases in shallow layers at the distant point in the river bottom $(-5)$. The point +10 displays a serious decrease at 1-2 m depth compared to other points on the beach showing an increase of $\mathrm{N}$. By far the least amount was recorded at the point $+200: 0.01 \mathrm{mg} / \mathrm{l}$.

\subsubsection{Chlorides}

Autumnal recordings in the river Sava amounted to $10.5 \mathrm{mg} / 1$ of chlorides and $17.5 \mathrm{mg} / 1$ in the spring. The former measuring indicated the least quantity of chloride recorded in the hyporheic during our studies.

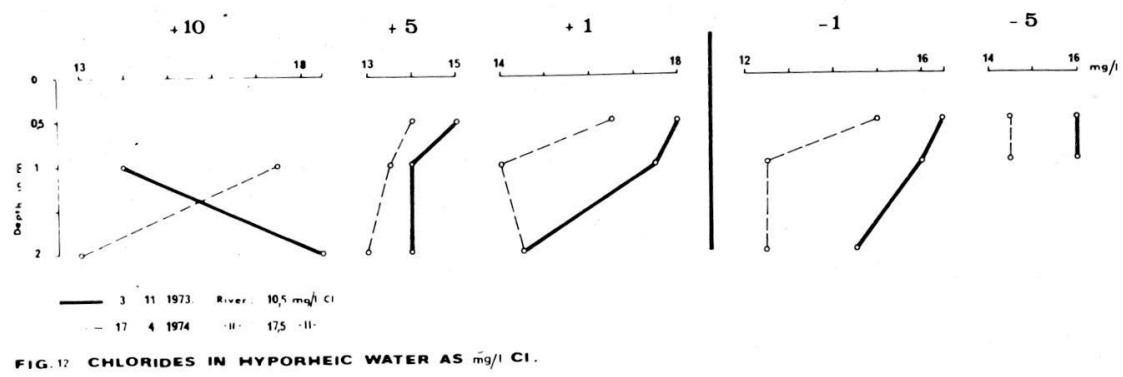

With an exception of the most distant part of the beach (point +10 ), where considerable increase was noticed down to $2 \mathrm{~m}$ depth, all other point showed a concentration of chlorides in a shallow surface layer. A notable decrease was recorded in deeper layers (Fig. 12)

3.4.7. Free carbon dioxide, $\mathrm{CO}_{2}$ (Fig. 13)

The measurements were carried out four times - on two occasions in the sum- 
INFLUENCE OF POLLUTION ON INTERSTITIAL WATER

347
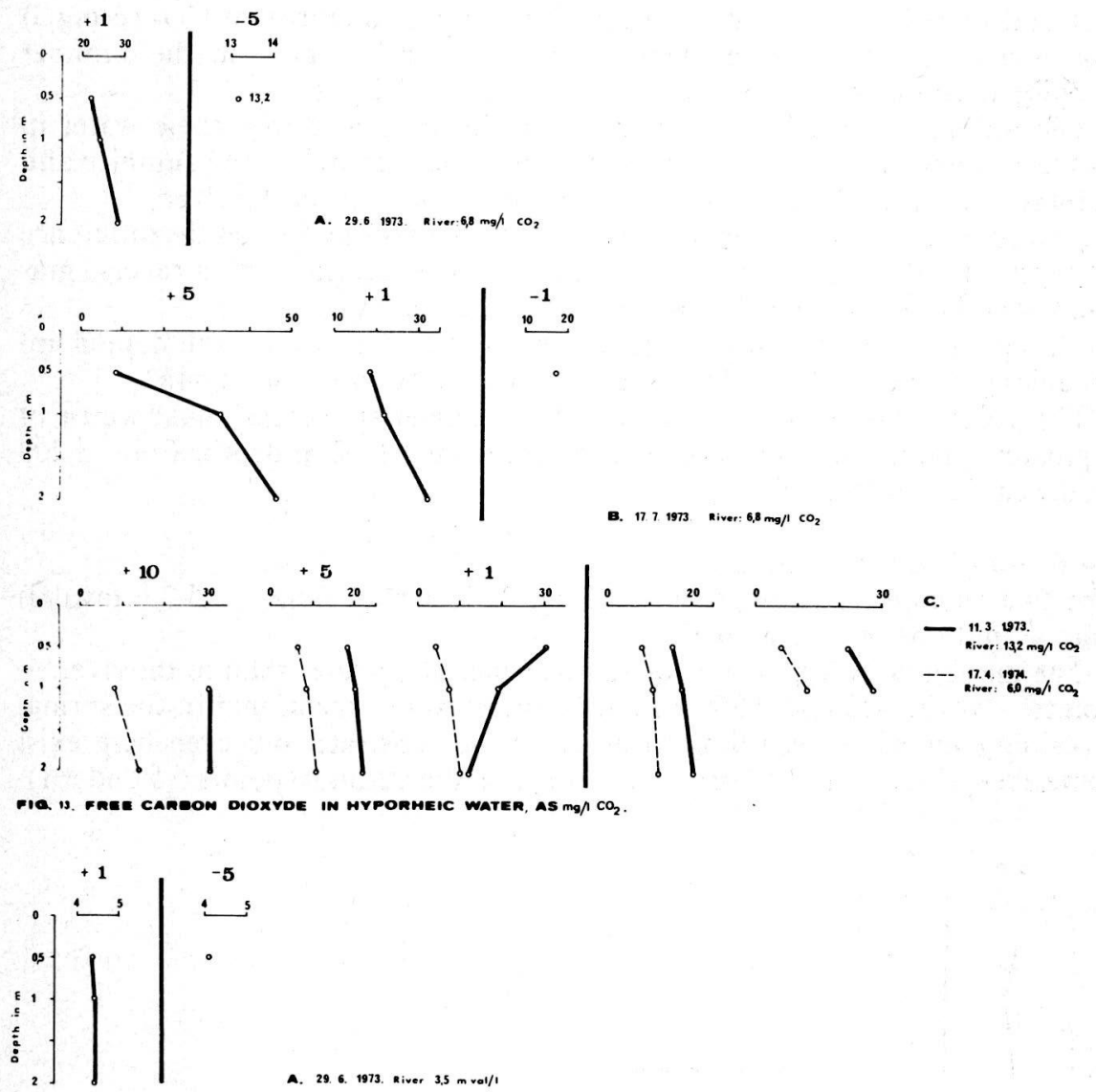

A. 29.6. 1973. River $3,5 \mathrm{mval} / \mathrm{l}$

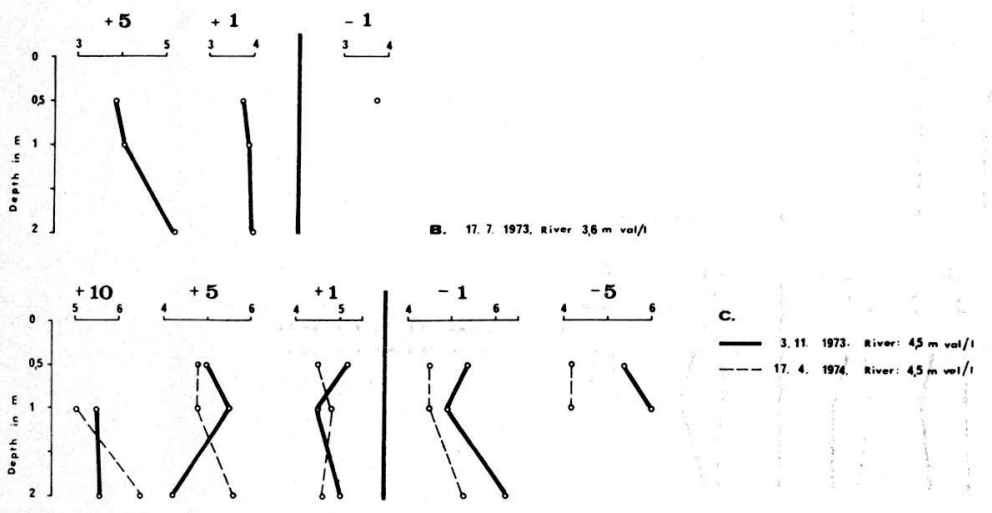

FIG. 14. ALKALINITY OF MYPOAMEIC WATER, IN mOIl. 
mer and once in autumn and spring. The minimal quantity of $\mathrm{CO}_{2}(6 \mathrm{mg} / \mathrm{l})$ was registrated in the river water in spring, slightly more in the summer $(6.8 \mathrm{mg} / \mathrm{l})$ and twice as much as in the autumn $(13.2 \mathrm{mg} / \mathrm{l})$.

The difference of $\mathrm{CO}_{2}$ content between the river and hyporheic water in spring is small in comparison with the differences found in the summer and autumn, i.e. up to 7 times more $\mathrm{CO}_{2}$ in hyporheic than in the river.

As a rule, $\mathrm{CO}_{2}$ content increase by depth, sometimes by 5 times the difference of depth of only $1.5 \mathrm{~m}$ (point +5 , summer). The exception with a reverse gradient was the beach near the river (point +1 , autumn).

The quantity of $\mathrm{CO}_{2}$ in the bores in the beach decreases at all depths approaching the edge of the river. Past the river bottom it rises again.

The points +10 in the autumn and +5 in summer are exceptional because of a greater quantity of $\mathrm{CO}_{2}$ in deeper layers from 1 to $2 \mathrm{~m}$ depth. Point +200 recorded $7.9 \mathrm{mg} / \mathrm{l}$ of $\mathrm{CO}_{2}$.

\subsubsection{Alkalinity (Fig. 14)}

The two summer recordings showed slightly lower alkalinity $(3.5-3.6 \mathrm{mval} / \mathrm{l})$ than vernal one $(4.5 \mathrm{mval} / \mathrm{l})$.

The alkalinity of hyporheic water was generally greater than in the river points -5 with 4.2 and +200 with $4.1 \mathrm{mval} / 1$ were exceptional in the spring. Alkalinity increases according to depth in the substrate, but even here exist some exceptions - at the bores in the beach in the autumn (points +5 and +1 ).
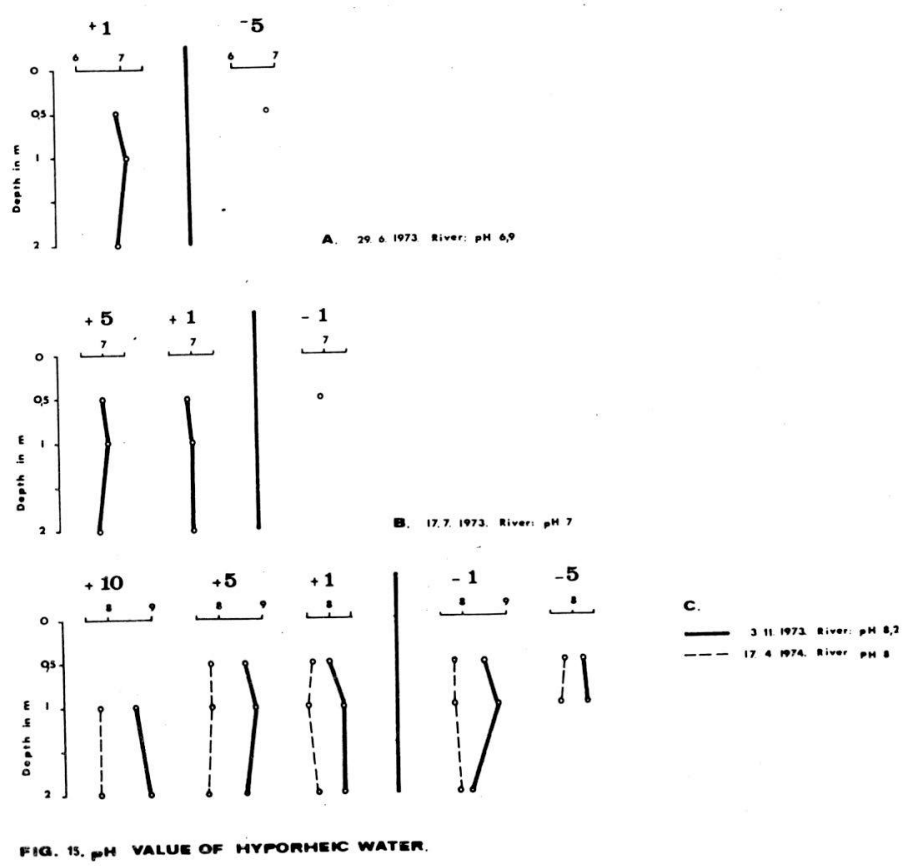


\subsubsection{Concentration of hydrogen ions, $p H$ (Fig. 15)}

The results of summer observations suggest neutrality of the river water: $\mathrm{pH}$ 6.9-7 and are considerably unlike the vernal $(\mathrm{pH} 8)$ and autumnal recordings (pH 8.2).

The summer $\mathrm{pH}$ values of subterranean water deviate quite inconsiderably from the river $\mathrm{pH}$. These values are slightly lower in the spring and a little higher in the autumn than the river seasonal $\mathrm{pH}$, but always over 7.5.

Generally, to a $1 \mathrm{~m}$ depth the $\mathrm{pH}$ moderately increases but to a depth of $2 \mathrm{~m}$ remains unchanged or records a slight increase or decrease. In the spring at $7 \mathrm{~m}$ depth (point +200$) \mathrm{pH}$ recorded 7.7.

There is a tendency to a slight decrease of $\mathrm{pH}$ in all depths in direction from the riverside toward the edge of the river and a rise in $\mathrm{pH}$ at the river bottom along the water's edge.

\subsubsection{Residues on evaporation and ignition. Loss during the ignition}

These analyses were carried out only for the samples of water taken on the 3rd November 1973, filtered through a cotton-wool filter.

The residues on evaporation and ignition have irregular values at all points and in all depths. The evaporated remains indicate an evaporated quantity of organic materials; ignition remains indicate, essentially, a quantity of inorganic materials and burned out organic materials.

The loss during the ignition (Fig. 16) represents these burned out materials.

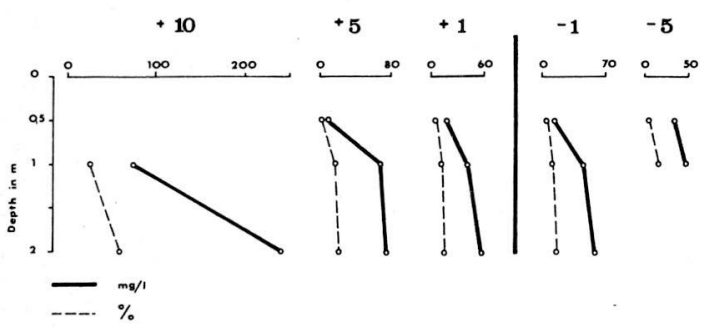

FIG.16. LOSS DURING THE IGNITION OF HYPORHEIC WATER, $\mathrm{N}$ mg/I AND IN $\%$.

The closer the locality is to the central portion of the river, the more organic materials noted in a $0.5 \mathrm{~m}$ deep surface layer. However, in deeper layers (0.5$2 \mathrm{~m}$ ), the more distant the localities are from the margin of river, - either toward the waterside or the central part of the river - the more abundant they are in organic materials. The point +10 and adjoining area in $2 \mathrm{~m}$ depth are particularly rich.

\subsubsection{Suspended matter (Fig. 17)}

The quantity of suspended particles increases at all points by depth. Also, it increases in all layers in a direction from the river to the waterside. An exceptionally great quantity was recorded at the point +10 in $2 \mathrm{~m}$ depth. Here, the quantity was registrated 20 times higher than in the $1 \mathrm{~m}$ deep layer. 


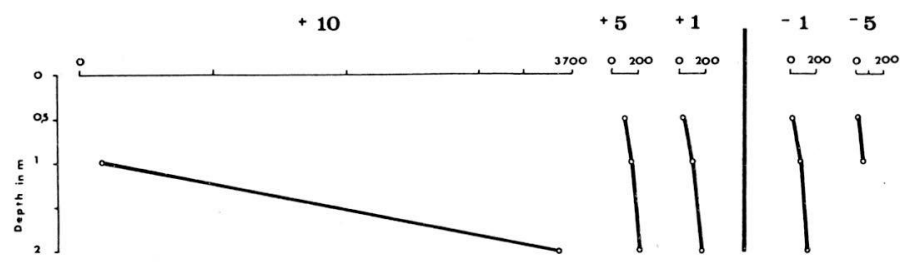

FIG. 17. SUSPENDED MATTER IN HYPORHEIC WATER (OS mg/I OF RESIDUE ON EVAPORATION)

3.4.12. Anionic surface-active agents ("surfactants" (Fig. 18)

Only vernal recordings were carried out. The river contained $0.2 \mathrm{mg} / 1$ of TBS. The quantity increases in the superficial layer of the river bottom and in the beach along the river. But only $0.08 \mathrm{mg} / 1$ of TBS was recorded in $0.5 \mathrm{~m}$ depth, $5 \mathrm{~m}$ distant from the edge of the river.

The surfactants penetrate the river bottom down to $2 \mathrm{~m}$ but in the alluvial soil only to $1 \mathrm{~m}$. The concentration increases everywhere by depth.

The presence of surfactants were not discovered at the points 10 and $200 \mathrm{~m}$ away from the river either in $1 \mathrm{~m}$ depth nor in $2 \mathrm{~m}$ and $7 \mathrm{~m}$ depth.

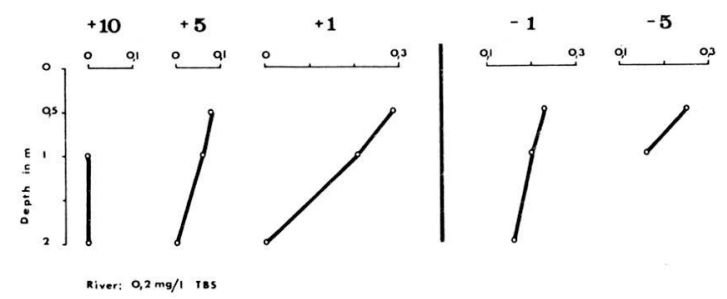

FiG. 18. ANIONIC SURFACE-ACTIVE AGENTS ("SURFACTANTS") IN hYPORHEIC WATER,AS mg/I TBS

\section{DISCUSSION AND CONCLUSIONS}

The studies of various relations between the biotopes of subterranean and surface waters have been undertaken at a relatively small locality in the river Sava valley near Zagreb. The studies have been carried out in the beach and in the river bottom down to $2 \mathrm{~m}$ depth. This is as deep as possible, considering the technical equipment. At the riverside the samples of water have been taken from the depth of $7 \mathrm{~m}$ by a permanently fixed pump i.e. slightly deeper than the level of subterranean water. The studies - considering cross section - have comprised a part of the river bottom and the whole beach of sand and gravel sediments which at high water forms a part of a waterside bottom and at low water is exposed. The studies of subterranean water $200 \mathrm{~m}$ away from the margin of the river have been made only once. Accordingly, all areas in vertical 
and horizontal sense which could be watered by the river's water have been included in our studies.

The greater part of the beach closer to the margin of the river rises so gently that even a slight rise of the water level is followed by an inflow and an effect on the substratum. More intensive depositing of transported material in this area than in a constantly submerged bottom of river is due to a frequent and slow inflow and outflow of the river water. This is also indicated by quantities of suspended material at all depths of measurements (Fig. 17).

Comparing the chemical and physical parameters taken simultaneously in the river and interstitial water, several different ecological areas could be separated:

- The most distant point from the river $(200 \mathrm{~m})$ where the water is at a depth of $7 \mathrm{~m}$ is situated in an area distinct both by space and some parameters. This point is remarkable with a small quantity and a greater deficiency of oxygen as well as low temperature. The quantity of $\mathrm{CO}_{2}$ is also considerably less than at all other bores. Alkalinity of $4.1 \mathrm{mval} / 1$ is the lowest recorded in the spring, and quantity of ammonia about 10 times less than in the interstitial water of the beach. This is the area of phreatic or eustigal which differs considerably by its characteristics from others, and in which a direct impact of the river could not be defined during the studies (Table V).

- The zone along the edge of water which extends some $5 \mathrm{~m}$ on the beach as well as on the river bottom is different from the surrounding area. The extend and changes both in space and time of physico-chemical and other parameters suggest the existence of various layers. Namely, some parameters in various depths $(0.5,1$ and $2 \mathrm{~m})$ of the same point of measure, produce considerable differencies in amount, but a regular rise of these values at each depth in direction from the river edge toward inland or reverse is notable as well. Also seasonal inversions - indicated, for example, in the quantity of oxygen in summer and autumn in a layer at $2 \mathrm{~m}$ depth - which keep its regularity as to the changes in a layer itself, evidence that the horizons in consideration have presumably diverse physical structures (granularity) (Fig. 6). Some indicators, such as more intensive bacteriological activities (heterotrphic bacteria), coliform bacteria, quantity of anionic surface-active agents, presence of populations of the species indicative of a higher degree of organic pollution such as Sphaerotilus natans etc., and the presence of river fauna, demonstrate that the hyporheic zone along the margin of river down to $1 \mathrm{~m}$ depth is more influenced by the river's water and its polluting effect than deeper and more distant zones (Fig. 2, 3, 18; Tables I, II, III).

- Some features of the part of the beach more distant from the margin of the river (point +10 ) differentiate this zone from the eustigal and from a wider area near the margin of the river; and various values of the parameters of point +10 and other points closer to the river suggest its characteristic feature. Here, the quantity of oxygen slightly varies by depth. There are more organic materials here than elsewhere in the alluvium as well as products of mineralisation of these organic materials. Perhaps many organic materials and chlorides originate from the surrounding meadows and agricultural areas, and presumably 


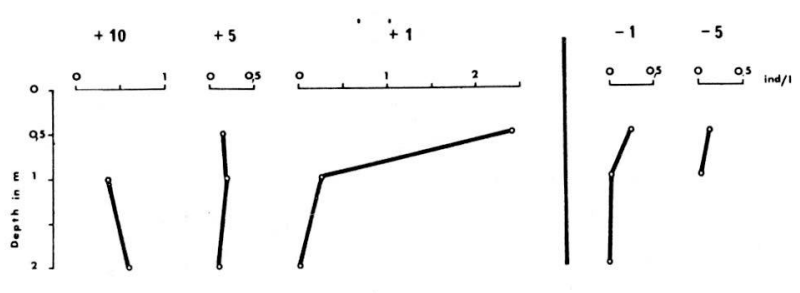

FIG. 19. NUMBER OF ANIMALS IN I LITER OF PUMPED HYPORHEIC WATER Save nearby Zagreb, $1973 / 74$.

Table IV. Groups of animals sampled in hyporheic of the river Save nearby Zagreb and Drave nearby villages D. Dubrava and Legrad.

GROUPS

Nematoda

Oligochaeta

Copepoda

Ostracoda

Amphipoda

Chironomidae

Trichoptera

Insecta, others

Gastropoda

(Sphaerotilus)

Ciliata (colon)

Hydrozoa

Acarina

I sopoda

Collembola

Coleoptera
SAVE

\section{Dubrava Legrad}

\section{Average of animals} per liter

0.63

1.3

2.2

Degree of saprobity

$\alpha-\mathrm{m}$

$\beta-\mathrm{m}$

$\alpha-\mathrm{m}$ 
only high-water causes a more intensive contact between river water and the subterranean water of alluvium.

Indicators of pollution like organic compounds, chlorides, nitrates, nitrites, ammonia and coli-bacteria show that all points on the beach and on the bottom of the river are subject to the influence of polluted river water at least down to $2 \mathrm{~m}$ depth. This is confirmed by particles of coal, Sphaerotilus and other indicators of saprobity present in the deepest examined horizon (Fig. 2, 8, 9, 10, 11, 12; Tables I, II).

The activity of bacteria - evidenced by the presence of products of organic material decomposition and BOD - suggest that the process of autopurification is also performed in hyporheic. Due to the oxygen demand - down to $1 \mathrm{~m}$ depth - the deficit of oxygen approaches $99 \%$. In deeper layers, in summer, oxygen disappears almost completely (Fig. 6).

In comparison with the physically similar habitat by the river Drava near Legrad, studied in the same year (Meštrov, Lattinger-Penko \& Tavčar 1976), the fauna of the Sava hyporheic is not as rich - in the quantitative and qualitative sense (Table IV; Fig. 19). Typically subterranean species of Acarina, Isopoda and Amphipoda are lacking here, otherwise living in phreatic water of the Sava valley (Meštrov 1960) and in the mentioned hyporheic of the Drava. It is supposed that macrocenobionts have a certain role in maintaining the "cleanness" and permeability of interstices, i.e. circulation of water through them. Eating the infiltrated detritus, they accelerate the process of decomposition and development of a balance in ionic and organic composition of water and open the crevices closed by this detritus (Husmann 1974, 1975; Bojcenko 1975).

Autumnal enrichment of the deep hyporheic layer of water by oxygen was not followed by a greater density or a changing composition of animal popu-

Table V. Physico-chemical analysis of the water from the point $+200(7 \mathrm{~m} \mathrm{depth}$, $200 \mathrm{~m}$ distance from the margin of the river)

Water temperature
Dissolved oxygen
Deficiency of oxygen

B.O.D.2

Permanganate number ( $\mathrm{KMnO}_{4}$ consumption)

Free carbon dioxide

$\mathrm{pH}$

Alkalinity

Chlorides, $\mathrm{Cl}$

Ammonia, $\mathrm{N}$

Nitrites, $\mathrm{NO}_{2}$

Nitrates, $\mathrm{NO}_{3}$

Anionic surface-active agents ("surfactants")
$8.5^{\circ} \mathrm{C}$
$0.8 \mathrm{mg} / \mathrm{l}$
$10.9 \mathrm{mg} / \mathrm{l}$
$93.2 \%$
$4.0 \mathrm{mg} / 1$
$57.1 \%$
$7.9 \mathrm{mg} / 1$
$7.9 \mathrm{mg} / \mathrm{l}$
7.7
$4.1 \mathrm{mval} / \mathrm{l}$
$14.5 \mathrm{mg} / \mathrm{l}$
$0.01 \mathrm{mg} / \mathrm{l}$
$0.03 \mathrm{mg} / \mathrm{l}$
$0.5 \mathrm{mg} / 1$
$0.0 \mathrm{mg} / \mathrm{l}$ 
lations considering stygobionts. The layers below $1 \mathrm{~m}$ depth in the studied locality of the Sava seem to be "ecologically devasted" (Husmann 1974/75). It is certain that the chronically high degree of pollution with organic and toxic materials (Meštrov, Dešković \& Tavčar 1976; Meštrov et al. 1976) causes this phenomenon. The results of our studies confirm this.

The continuation of comparative ecological researches and studies of deeper layers will disclose more information and explanations.

\section{SUMMARY}

Because of the fundamental biological investigations and also of the practical importance, the authors investigated interstitial subterranean water (hyporheic) near a polluted river Sava in the plain where the underground waters are considered as potable. With the comparison of the physical, chemical, bacteriological, saprobiological and faunistic characteristics of river and its hyporheic in different seasons their mutual relation is detected. The results show the influence of polluted river water on the hyporheic water within the river bed to at least $2 \mathrm{~m}$ depth.

\section{RÉSUMÉ}

A cause des recherches biologiques fondamentales comme à cause d'une importance pratique aussi, les investigations d'eau souterraine interstitielle (hyporhéique) sont effectuées le long d'une rivière polluée (Save).

En comparant les propriétés physiques, chimiques, bactériologiques, saprobiologiques et faunistiques de la rivière et de son hyporhéique en saisons différentes, leur influence mutuelle est recherchée. Les résultats obtenus montrent l'influence de l'eau de la rivière polluée sur l'eau hyporhéique de son lit jusqu'au profondeur de deux mètres au minimum.

\section{REFERENCES}

BOJČENKO, M. M., 1975: O formirovanii kačestva vodi gidrobiontami. Nauč. dokl. viss. školi Biol.n., 4, 74-77.

DANIELOPOL, D. L., 1976: The distribution of the fauna in the interstitial habitats of riverine sediments of the Danube and the Piesting (Austria). Int. J. Speleol., 8, 23-51.

GIAMMONA, Ch. P., 1973: Fluorescent Dye Determination of Groundwater Movement and Contamination in Permeable Rock Strata. Int. J. Speleol., 5, 201-208.

HUSMANN, S., 1964: Morphologische, ökologische und verbreitungsgeschichtliche Studien über die Bathynellen (Crustacea, Syncarida) des Niederrhein-Grundwasserstromes bei K refeld. Gewässer und Abwässer, 37/38, 46-76.

1968: Langsamfilter als Biotopmodelle der experimentalökologischen Grundwasserforschung. Gewässer und Abwässer, 46, 20-49.

1971: Die gegenseitige Ergänzung theoretischer und angewandter Grundwasser-Limnologie; mit Ergebnissen aus Wasserwerken Wiesbadens. Die Sicherstellung der Trinkwasserversorgung Wiesbadens. Stadtwerke Wiesbaden AG. 
1974: Die ökologische Bedeutung der Mehrzellerfauna bei der natürlichen und künstlichen Sandfiltration. Künstliche Grundwasseranreicherung am Rhein. Wissenschaftliche Berichte über Untersuchungen u. Planungen der Stadtwerke Wiesbaden AG, 2, 173-183. 1974/75: Versuche zur Erfassung der vertikalen Verteilung von Organismen und chemischen Substanzen im Grundwasser von Talauen und Terrassen; Methoden und erste Befunde. Int. J. Speleol., 6, 271-302.

1975: Die Schotterufer des Niederrheins bei K refeld: abwasserkranke Biotope mit gestörter Uferfiltration. Gewässer und Abwässer, 57/58, 7-26.

LÜPKES, G., 1976: Die vertikale Verteilung von Ciliaten im Stygorhithral der Fulda (Beitrag zur Kenntnis mesopsammaler Ciliaten in Fliessgewässern). Int. J. Speleol., 8, 127-133.

MESTROV, M., 1960: Faunisticko-ekoloska i biocenoloska istrazivanja podzemnih voda savske nizine. Biol. glasnik., 13, 73-109.

MESTROV, M., LATTINGER-PENKO, R. \& TAVCAR, V., 1976: La dynamique de population de l'Isopode Proasellus slavus ssp.n. et les larves de Chironomides dans l'hyporhéique de la Drave du point de vue de la pollution. Int. J. Speleol., 8, 157-166.

MESTROV, M., DESKOVIĆ, I. \& TAVCAR, V., 1976: Saprobiological and physico-chemical researches of the river Sava in the course of several years. Bull. sci. 21, 7-9, 145-146.

MESTROV et al., 1976: Oekologische Untersuchungen der Flusstrecke des Flusses Sava stromabwärts von Zagreb (Oborovo-Tisina) I. Die Gestaltung und Anordnung von Biozönozen und physisch-chemische Eigenarten des Flusses Sava. Bull. sci. Sect. A Yougosl. 21, 1012, 205-206.

RITTERBUSCH, B., 1976: Untersuchungen zur Funktion des Mesopsammon bei der Reinigung von infiltrirtem Oberflächenwasser. Int. J. Speleol., 8, 185-193.

SPANGENBERG, H-J., 1973: Faunistisch-ökologische Untersuchungen an Gewässern von Gipshöhlen und im Grundwasser des Südharzes und Kyffhäusers. Int. Revue ges. Hydrobiol., $58,4,501-541$. 